\title{
LINKING WORKING CAPITAL POLICY TOWARDS FINANCIAL PERFORMANCE OF SMALL MEDIUM ENTERPRISE (SME) IN MALAYSIA
}

\author{
Nor Edi Azhar Binti Mohamad*1, Noor Raida Binti Abd Rahman², Noriza Binti Mohd Saad ${ }^{1}$ \\ Finance and Economic Department, The National Energy University UNITEN \\ Accounting Department, The National Energy University UNITEN
}

\begin{abstract}
Despite the fact that working capital management (WCM) is vital to businesses of any size that operated in developed and emerging countries, WCM is of particular importance to the small business firms operating in emerging markets. The importance of WCM to small and mediumsized enterprises (SMEs) stems from the limited financial resources available and heavily reliance of SMEs on WCM as a main source of finance. This study aims to provide empirical evidence on the effects of working capital investment policy on firm's financial performance for a sample of 103 small and medium-sized firms listed with the SME Corporation of Malaysia. Data for the period from 2008 to 2013 are analysed to examine if investment policy improves firms' return on total asset. By using correlation and pooled ordinary least square regression, the result provides a significant relationship between the level of aggressiveness of investment policy and SME's financial performance. The findings of this study not only contribute to the scant WCM literature in Malaysia but throw light on the importance of efficient WCM to the policy makers and regulators in motivating and encouraging relevant parties to pay more attention on working capital through improving investors' awareness and improving transparency.
\end{abstract}

Keywords: Working Capital Management, Small and medium-sized enterprises, Working Capital Investment Policy, Return on Total Asset

\section{INTRODUCTION}

Small and medium-sized enterprises (SMEs) are the backbone of the resilient national Economy in boosting domestic ultimatum. SMEs have been identified as a significant contributor of the economy particularly those from an emerging countries (Hashim, 2015). In Malaysia, there was a total of 662,939 SMEs operating their businesses, represents over $97 \%$ of the total business establishments and contributes for more than one-third of the total Malaysian GDP (SME Annual Report, 2013). Notwithstanding the remarkable achievement of a number of SMEs, nevertheless, many more still struggle to ensure long-term growth, profitability and survival (Lyngstadaas and Berg, 2016). Even for a firm with favorable longrun prospects, inattention to efficient working capital management (WCM) may cause severe difficulties and losses due to adverse short-run developments (Pais and Gama, 2015).

*Corresponding author's email: NorEdi@uniten.edu.my 
The implication of efficient WCM for the betterment of the firm has been discussed in the previous studies (Park, 1951). It is considered as one of the key indicators of the firms' financial health (Altman, 1968) and also proven as one of the significant factors causing industrial sickness (Yadav, 1986). Past researches depicted that poor WCM and inadequate long-term financing are the main cause of failure among small businesses (Ramiah, Zhao and Moosa, 2014). Inefficient WCM might lead to tying ups the important sources of funds in an unproductive assets which contribute towards reducing the firm's liquidity and profitability (Panigrahi, 2013).

Given the limited financial resources available to SMEs and rely heavily on WCM as a vital source of finance as compared to its larger counterparts (Tauringana and Afrifa, 2013)., effective management of their working capital is vital to SMEs than to larger firm (Afrifa and Padachi, 2016). Yet, there is still less attention paid to this issue academically, particularly in Malaysia (Wasiuzzaman, 2015). It is interesting to know how the working capital policy influences the profitability of SMEs in the Malaysia, as an emerging market, given that over the years Malaysian firms showed unsatisfactory working capital performance (Wasiuzzaman, 2015). Additionally, with the diverse economic conditions and culture, it is likely that investors in Malaysian have a different view and approach on the level of working capital compared to investors in the other countries. Therefore, the objective of this study is to investigate the link between WCM policy and financial performance of 103 Malaysian SMEs firm during the period 2008 to 2013. In this study, greater emphasised is given on the asset management as it is one of the important components of working capital. The result of the study supports the current use of a conservative WCM strategy.

This study is pertinent for a number of reasons. First, it contributes to the existing WCM literature. While at the international level, there is considerable literature on WCM (Wasiuzzaman, 2015), this study adds to the limited literature on WCM issues in Malaysia, which mainly focuses on SMEs. Second, this study helps the management of SMEs to prioritise their scarce resources to manage working capital component that are relatively significant for their profitability. Third, the finding is of important for regulators and policy makers in motivating and encouraging relevant parties to pay more attention on working capital.

The paper proceeds as follows. Section 2 reviews previous studies on issues related to working capital and performance. Then the research methodology employed in this study is introduced and explained in Section 3. Next the discussion of the results is presented in Section 4, followed by a conclusion and suggestions for future research in the last section.

\section{LITERATURE REVIEW}

Tradeoff theory delineates that firms need to keep a balance between liquidity and profitability (Abuzayed, 2012). The firm's WCM has a significant influence on its liquidity and profitability, hence the health of businesses (Singh and Kumar, 2014). The adopted policy choose by the firms will influence investment level in working capital (Afrifa, 2016; GarciaTeruel and Martinez-Solano, 2007). Normally, a firm may adopts either an aggressive or conservative working capital policy by reducing or increasing the level of investment in working capital (Afza and Nazir, 2011; Nazir and Afza, 2009; Tauringana and Afrifa, 2013). The firm's ability in optimising the required amount of working capital in which could boost 
firm's profitability and creating more market value with minimization in risks was considered as an optimal policy (Nobanee, Abdullatif and AlHajjar, 2011).

The working capital policy provides a guideline for the firm to manage the current assets and current liabilities with the main objective of reducing default risk (Afza and Nazir, 2007). The conservative approach is a strategy that keeps a large amount of capital in current assets as compared to the fixed-assets, thus it will increase investment in working capital (Garcia-Teruel and Martinez-Solano, 2007). This strategy will help the firms to reduce the risk of short-term cash shortage, nevertheless for long-term it might affect the profitability. Additionally, expanding investment in working capital may result in opportunity cost of cash tied-up in the unproductive assets such as inventory and accounts receivable (Tauringana and Afrifa, 2013). Thus, by adopting this strategy, the firms obtain a lower expected profitability resulting in a lower risk (Nwankwo and Osho, 2010).

In contrast, firms adopting the aggressive approach will gain higher profitability that result from higher risk and lower working capital (Nwankwo and Osho, 2010). This approach would positively affect the profitability of the firm, by reducing the proportion of its total assets in the form of net current assets (Garcia-Teruel and Martinez-Solano, 2007). Nonetheless, the aggressiveness of WCM resulted in capital being minimised in current assets over fixed-asset might increase the liquidity risk. Additionally, firms that used the long-term capital to finance all of its fixed assets and used short-term credit to finance parts of its current assets could lead to risk of default and bankruptcy risk (Weinraub and Visscher, 1998).

Weinraub and Visscher (1998) is considered as one of the pioneers discussing the aggressive and conservative WCM policies. From their observation, the author found that each industry had a different WCM policies. Many researchers have established a relationship between WCM and profitability (Sing and Kumar, 2014). In the preceding studies, the findings on the WCM - profitability nexus are mixed. Some supported conservative strategy of WCM, arguing that the higher the working capital, the higher the profitability of the firm. The association between cash conversion cycle (CCC), a component used as a measure of working capital skill; and profitability was found to be positive and significant by researchers including Abuzayed ( 2012), Afrifa and Padachi (2016), Gill, Biger and Mathur (2010) and Samiloglu and Demirgunes (2008). The authors concluded that the higher the CCC, the higher the profitability of the firm.

Using data from 52 firms listed in Amman Stock Exchange for the period from 2000 to 2008, Abuzayed (2012) found a significant positive relationship between CCC and profitability. The result showed profitable firms less motivated in managing their working capital. Afrifa and Padachi (2016) made use of a sample of 160 Alternative Investment Market (AIM)-listed SMEs for the period from 2005 to 2010 to accentuate the relationship between WCM and profitability. The authors recorded that the profitability increase as CCC level increase; nevertheless it then starts to decline if it rises beyond a certain level. Similarly, Afrifa (2016) reported a strong concave relationship between net working capital and performance of 6,926 SMEs in the UK. However, when the manager is considering cash flow in working capital, the performance of the firms is improving.

In line with the aggressive strategy of WCM, Al-Shubiri (2011), Garcia-Teruel and MartinezSolano (2007), Lyngstadaas and Berg (2016), Nobanee et al. (2011) and Pais and Gama, (2015) reported a negative relationship between WCM elements and profitability. In the Spain context, 
Garcia-Teruel and Martinez-Solano (2007) tested the effects of WCM of 8,872 Spanish SMEs on the firm profitability. The finding demonstrates that managers can create value by reducing their inventories and the number of days for which their accounts are outstanding.

A study conducted by Al-Shubiri (2011) for a sample of Amman Industrial Firms listed in Amman Stock Exchange for the period of 2004 to 2007 also indicates that firm's obtained a negative returns if the firm's follow aggressive working capital policy. The author argued that funds committed to working capital can be seen as hidden sources that could be utilized to improve profitability of the firm.

In a recent study, Pais and Gama (2015) examined the effects of WCM on the profitability of 6,063 Portuguese SMEs firms from the year 2002 to 2009. While, Lyngstadaas and Berg (2016) assessed the relationship between profitability of 21,075 SMEs and the inventory, accounts payable, accounts receivables and CCC variables for the period 2010 to 2013 in Norway. In Japan, Nobanee et al. (2011) examined the relation between CCC and firm profitability of 34,771 non-financial firms listed on the Tokyo Stock Exchange from 19902004 All of these studies concluded that by shortening the CCC firm's profitability could be improved. By shortening the length of $\mathrm{CCC}$, external financing is unneeded, thus increasing profitability due to fewer borrowing cost and interest expense.

The studies for Malaysian sample were done by Zariyawati, Annuar, Taufiq and Rahim, (2009), Mohamad (2013) and Wasiuzzaman (2015). Zariyawati et al. (2009) examined the relationship between the length of the CCC and profitability of 148 companies in six different economic sectors over 1996-2006 periods. Their analysis provides a strong negative significant relationship between CCC and firm profitability. Mohamad (2013) examined the relationship between return factors and the firm's WCM policy of 370 companies listed in Bursa Malaysia. The finding indicated a significant positive relationship between both variables. In addition, the finding showed a negative/(positive) relationship between the degrees of aggressiveness/(conservativeness) of the firm's financing policy with the performance measurements. In a recent study, Wasiuzzaman (2015) examined the relationship between working capital efficiency and firm value of 192 firms spanning a period of ten years (19992008). The finding reveals that there is a negative impact of net operating working capital on firm value, implies that investors prefer firms which follow a more restrictive working capital policy. Nevertheless, these studies do not focus the effect of WCM and financial performance of SMEs. Based on the previous researches presented in this section, the following hypothesis is developed.

\section{H1: There is a significance relationship between working capital policy and SME's financial performance}

\section{RESEARCH METHODOLOGY}

\section{Sample and Data}

To accomplish the aforementioned research objectives, this study focuses SMEs listed in SME Corporation Malaysia for 6 years basis ranging from year 2008 to 2013. A sample of 250 annual reports of the selected SMEs was obtained from the Suruhanjaya Syarikat Malaysia. However, only 103 companies were valid for the analysis after deducting the companies with 
missing information and also companies that reported a loss for more than four consecutive years.

\section{Variables}

Financial performance is dependent variable, with Return on Total Assets (ROTA) as a proxy for profitability. Financial performance was considered as an indicator of a firm's financial health over a given period of time. The SME is categorized based by a low fixed asset that relied more towards accounts payable in funding its gross working capital (Padachi, 2006). Thus, in capturing its financial performance, ROTA could serve as an appropriate indicator in capturing the return towards total assets in which also cover for SME's total liability.

Following Weinraub and Visscher (1998), Nazir and Afza (2009) and Mohamad (2013), this study utilised investment policy (IP) as a proxy for working capital policy. The IP represent the level of investment in current assets versus fixed assets, which act as independent variable for this study. The conservative policy is used in explaining an increase in the level of investment in the current assets. Conversely, an aggressive policy was represents by investing fewer amounts in current assets. The following ratio was used to measure the degree of aggressiveness, in which the lower ratio indicates a relatively conservative policy:

\section{Investment Policy $(I P)=$ Total Current Assets $/$ Total Assets}

\section{(1)}

Others independent variables selected for the study are account payable turnover (APTO), account receivable turnover (ARTO) and cash $(\operatorname{lgCASH})$ to represent the important component of working capital. ARTO was used to indicate the number of times per year the SMEs collect its average accounts receivable. It implies the SME's efficiency in using its asset in generating the revenue. The account receivable brings a positive impact towards an increase in working capital since it signify cash in terms of current assets components that should be received by the firms within a relatively short time period, ranging from a few days to years. The ratio can be calculated by dividing the credit sales with average account receivable. The higher the ratio indicates the SME's efficiency in the collection of receivable.

Account payable denotes the credit terms given by the suppliers or trade credit due to the supply of goods and services rendered to the firms (Okinyi, 2014). Account payable is also considered as a significant source of short-term financing available to the firms with minimum cost. The effective management of account payable might serve as indicator of SMEs overall operational effectiveness (Kallikkat, 2013). The higher the account payable might indicating problems in resolving payment to suppliers (Deloitte, 2015) while lower payables indicating firm's had waste the benefits of investment for the available cash by early settlement of the suppliers invoices (Kallikkat, 2013). The account payable turnover (APTO) measures the speeds of SME abilities in paying its suppliers. The ratio can be calculated by dividing the total purchases made from suppliers, or cost of sales with average account payable. The lower the ratio indicates inefficiency in payment policy thus could signify deteriorating in financial conditions.

$\operatorname{lgCASH}$ is used as proxy for cash. It is measured based on the log value of cash and cash equivalent hold by SMEs. Pastor and Gama (2013) believe SMEs hold large amounts of cash and cash equivalents for a various reasons. The higher level of cash hold might reduce the 
possibility of financial distress; representative towards firm's optimal investment policy; and potential contribution towards effective used of cost of external financing resources (Ferreira and Vilela, 2004).

\section{Estimation}

The relationship between the SME's financial performance and WCM policy is estimated using the following regression equations:

ROTA $=\alpha+{ }_{\beta 1} I P_{1}+{ }_{\beta 2} A_{R T O}+{ }_{\beta 3} A P T O_{3}+{ }_{\beta 4} l g C A S H+e$

where ROTA is return on total assets; IP, investment policy; ARTO, accounts receivable turnover; APTO, account payable turnover; $\operatorname{lgCASH}, \log$ value of cash and cash equivalent and $\varepsilon$, residual error (unobservable factors that vary over time and affect ROTAi,t). in order to analyse the data, this study applied panel data methodology. A F-test was used to decide if fixed effect models are preferred over the pooled OLS, with the null hypothesis that all fixed effect intercepts are zero.

\section{RESULTS AND DISCUSSION}

\section{Result and Analysis}

The objective of this study is to investigate the link between WCM policy and financial performance of 103 Malaysian SMEs firm during the period 2008 to 2013. The following sections discuss the relevant analysis to achieve this objective.

\section{Correlation Analysis}

Table 1 presents the Pearson correlation matrix for the variables. Results indicated that there is no multicollinearity problems as the correlations were relatively low. According to Gujarati (2004), multicollinearity problems exist when the correlations value exceeded 0.80 . The correlations results for ROTA indicated a positive significant coefficient with IP (0.258) and

Table 1. Correlations Analysis

\begin{tabular}{lccccc}
\hline & ROTA & IP & ARTO & APTO & IgCASH \\
\hline ROTA & 1 & $.258^{* *}$ & -.043 & .035 & $.095^{*}$ \\
IP & $.258^{* *}$ & 1 & -.009 & -.019 & $.085^{*}$ \\
ARTO & -.043 & -.009 & 1 & $.141^{* *}$ & $-.088^{*}$ \\
APTO & .035 & -.019 & $.141^{* *}$ & 1 & -.026 \\
$\operatorname{lgCASH}$ & $.095^{*}$ & $.085^{*}$ & $-.088^{*}$ & -.026 & 1 \\
\hline
\end{tabular}

**. Correlation is significant at the 0.01 level (2-tailed).

*. Correlation is significant at the 0.05 level (2-tailed

$\operatorname{lgCASH}(0.095)$ at $1 \%$ and $5 \%$ significant level respectively. This result of the study is in line with the study conducted by Mohamad (2013). The magnitude of the Pearson correlation coefficient determines the strength of the correlation but there is no rule in assigning strength of association to particular values. Yet, some general guidelines are provided by Cohen, Cohen, West and Aiken (2003), indicating a coefficient with $r<0.3$ does indicate a small coefficient. Although results of the estimated correlation coefficient indicate negative and positively 
correlated within the selected variable, however it still considers low; therefore, it is not large enough to cause any concern in the regression model.

\section{Multiple Regressions}

Table 2 contains result of estimation involving ROTA. To quantify the severity of multicollinearity for this study, the variance inflation factor (VIF) test was performed. The VIF results designate a very low level of multicollinearity since the VIF value for all variable tested is less than 10. VIF is simply the reciprocal of Tolerance (i.e., 1 divided by Tolerance). The results will indicates a sign of collinearity problem if the Tolerance value is less than 0.1 ; which is a VIF of greater than 10 .

Based on Table 2, the Collinearity Statistics indicates that all the Tolerance values are greater than 0.1 (the lowest is 0.973 ). Thus results depict no problem of collinearity in this particular data set. Even though there is no formal VIF value, however, values of VIF that exceed 10 are often regarded as indicating multicollinearity (e.g., Hair, Anderson, Tatham and Black, 1995). In addition, there was independence of residuals, as assessed by a Durbin-Watson statistic 2.023. The Durbin-Watson statistic can range from 0 to 4 , but a value of approximately 2 indicates that there is no correlation between residuals. Based on the results, the value is very close to 2, so it can be accepted that there is independence of errors (residuals).

Results of the regression analysis in Table 2 signify support the research hypothesis. The results for ROTA depicted a significant positive coefficient with IP $(+6.461)$ at $1 \%$ significant level. The positive coefficients of ROTA and IP signified a negative relationship between the degrees of aggressiveness in firm's investment policy with the performance measurements. Additionally, an increase in IP indicated a conservative's management of investment policy which emphasize more investment in liquid assets (Weinraub and Visscher, 1998).

The results support the implementation of conservative investment policy among SME's in Malaysia. The result is consistent with Nazir and Afza (2009) and Mohamad (2013) which also indicating a positive relationships between ROTA and conservative investment policy. Surprisingly, the result is similar with the study conducted by Mohamed (2013) for listed firms in Bursa Malaysia. The consistent result signifies that Malaysian SMEs have a working capital policy similar with its larger counterpart.

Table 2. Regression Results of ROTA and Working Capital Policy

\begin{tabular}{lcccccc}
\hline & B & Std. Error & $\mathbf{t}$ & Sig. & \multicolumn{2}{c}{ Collinearity Statistics } \\
Variable /Indicator & \multicolumn{7}{c}{ Tolerance } & VIF \\
\hline IP & 6.017 & .931 & 6.461 & $.000^{* *}$ & .992 & 1.008 \\
ARTO & -.014 & .013 & -1.042 & .298 & .973 & 1.028 \\
APTO & .030 & .025 & 1.220 & .223 & .980 & 1.021 \\
lgCASH & 1.197 & .656 & 1.824 & $.069 *$ & .985 & 1.015 \\
R & \multicolumn{7}{c}{0.274} \\
R Square & 0.075 \\
F (p-value) & $12.447(0.000)$ \\
df & $(4,612)$ \\
D-Watson & \multicolumn{7}{c}{} \\
** Correlation is significant at the 0.01 level (2-tailed) \\
*Correlation is significant at the 0.10 level (2-tailed).
\end{tabular}


In addition, $\operatorname{lgCASH}(+1.824)$ also indicated a positive significant relationship with ROTA at $10 \%$ significant level. The finding implied that cash is an important component of working capital management for SMEs. The result supports the Kinz's theory in which firms hold a certain amount of cash for precautionary, transactional and speculative purposes (Pastor and Gama, 2013). Also, consistent with Abel (2008), cash is a vital component for every business in boosting firm's survival and wealth.

Overall, the regression results support hypotheses 1 . As depicted in Table 2, the F statistics is substantiated at the $1 \%$ significant level for ROTA (12.447). Therefore, the results implied that the null hypotheses can be rejected at $1 \%$ level of significant. Hence the estimated regressions for hypotheses 1 is efficient for predictions, and the hypotheses can be accepted implying that there are an association between investment policy with SME's financial performance in Malaysia.

\section{CONCLUSION}

This paper seeks to investigate the influences of WCM policy towards SME's financial performance from the Malaysian perspective. This study tested ROTA model with the working capital policy for 103 selected SME listed with SME Development Corporation of Malaysia for the period of 2008 to 2013. Based on the findings of the study, it can be concluded that there is a significant relationship between firm's WCM policies and SME's financial performance.

This study provides significant contribution towards the literature on working capital policy for SME by identifying the conservative and aggressive working capital management from Malaysian perspective. However, the major limitation of the study is that it focused on a small SMEs sample size over a period of 2008-2013 and not extending it further and therefore generalization of the findings is restricted. In addition, the study do not considered moderating or mediating influence on the relationships between WCM and financial performance. For future study, it is suggested to use more samples of SMEs, testing with others variables as a proxy for SME's financial performance for an extended period; and also considering the moderating or mediating variables that can mitigate the inconclusive finding on the relationship between WCM and financial performance.

\section{REFERENCES}

Abuzayed, B. (2012). Working capital management and firms' performance in emerging markets: the case of Jordan. International Journal of Managerial Finance, 8(2), 155-179. http://doi.org/10.1108/17439131211216620

Afrifa, G. A. (2016). Net working capital, cash flow and performance of UK SMEs. Review of Accounting and Finance, 15(1), 21-44. http://doi.org/10.1108/RAF-02-2015-0031

Afrifa, G. A., \& Padachi, K. (2016). Working capital level influence on SME profitability. Journal of Small Business and Enterprise Development, 23(1), 44-63. http://doi.org/10.1108/JSBED-01-2014-0014 
Afza, T., \& Nazir, M. S. (2007). Is It Better To Be Aggressive or Conservative in Managing Working Capital? Journal of Quality and Technology Management, 3(2), 1-15. Retrieved from http://www.ciitlahore.edu.pk/Papers/Abstracts/146-8588087935136570808.pdf

Afza, T., \& Nazir, M. S. (2011). Working Capital Management Efficiency of Cement Sector of Pakistan. Journal of Economics and Behavioral Studies, 2(5), 223-235. Retrieved from http://www.researchgate.net/publication/233842286_Working_Capital_Management_Ef ficiency_of_Cement_Sector_of_Pakistan

Al-Shubiri, F. N. (2011). Analysis of the relationhsip between working capital policy and operating risk: An emperical study on Jordian Industrial companies. Hebron University Research Journal, 6(1), 287-306. http://doi.org/10.1017/CBO9781107415324.004

Altman, E. I. (1968). Financial ratios, descriminant analysis and the prediction of corporate bankruptacy. The Journal of Finance, XXIII(4), 589-609.

Cohen, J., Cohen, P., West, S., \& Aiken, L. (2003). Applied Multiple Regression / Correlation Analysis for the Behavioral Sciences. 2nd Ed Hillsdale NJ Lawrence Erlbaum Associates, Third Edit, 703 S. http://doi.org/10.2307/2064799

Deloitte. (2015). Strategies for optimizing your accounts payable. Retrieved from https://www2.deloitte.com/content/dam/Deloitte/ca/Documents/finance/ca-en-FAstrategies-for-optimizing-your-accounts-payable.pdf

Ferreira, M. A., \& Vilela, A. S. (2004). Why do firms hold cash? Evidence from EMU Countries. European Financial Management, 10(2), 295-319. http://doi.org/10.1111/j.1354-7798.2004.00251.x

Garcia-Teruel, P. J., \& Martinez-Solano, P. (2007). Effects of Working Capital Management on SME Profitability. International Journal of Managerial Finance, 3(2), 164-177. http://doi.org/10.2139/ssrn.894865

Gill, A., Biger, N., \& Mathur, N. (2010). The relationship between working capital management and profitability : Evidence from the United States. Business and Economics Journal, 2010(1), 1-9. http://doi.org/10.18052/www.scipress.com/ILSHS.20.14

Gujarati, D. N. (2004). Basic Econometrics. New York. http://doi.org/10.1126/science.1186874 Hair, J. F., Anderson, R. E., Tatham, R. L., \& Black, W. C. (1995). Multivariate Data Analysis: With Readings. Statistics (Vol. 151). http://doi.org/10.2307/2983017

Hashim, Ff. (2015). SMEs' impediments and developments in the internationalization process: Malaysian experiences Fariza. World Journal of Entrepreneurship, Management and Sustainable Development, 11(2), 100-119. http://doi.org/10.1108/WJEMSD-05-20140012

Kallikkat, S. (2013). Effectively Managing Accounts Payable. Available at: https://clarity.sutherlandglobal.com/blog/accounting-minute/effectively-managingaccounts-payable. [Retrieved on 5 July 2016]. 
Lyngstadaas, H., \& Berg, T. (2016). Working capital management: evidence from Norway. International Journal of Managerial Finance, 12(3), 295-313. http://doi.org/10.1108/IJMF-01-2016-0012

Mohamad, N. E. A. (2013). An analysis of working capital management with reference on listed companies in Bursa Malaysia. American Journal of Economics, 3(6), 352-357. http://doi.org/10.5923/j.economics.20130306.16

Nazir, M. S., \& Afza, T. (2009). Impact of Aggressive Working Capital Management Policy on Firms' Profitability. IUP Journal of Applied Finance, 15(8), 19-30. http://doi.org/10.5897/AJBM11.326

Nobanee, H., Abdullatif, M., \& AlHajjar, M. (2011). Cash conversion cycle and firm's performance of Japanese firms. Asian Review of Accounting, 19(2), 147-156. http://doi.org/10.1108/13217341111181078

Nwankwo, O., \& Osho, G. S. (2010). An empirical analysis of corporate survival and growth: Evidence from efficient working capital management. International Journal of Scholarly Academic Intelectual Diversity, 12(1), 1-13. Retrieved from http://www.nationalforum.com/Electronic Journal Volumes/Nwankwo, Odi - An Empirical Analysis of Corporate Survival and Growth IJSAID V12 N1 2010.pdf

Okinyi, B. (2014). Effect of working capital management on financial performance of five star hotels in Nairobi country. Interdisciplinary Journal of Contemporary Research in Business, 2(1), 75-79.

Padachi, K. (2006). Trends in working capital management and its impact on firms' performance: An analysis of Mauritian small manufacturing firms. International Review of Business Research Papers, 2(2), 45-58.

Pais, M. A., \& Gama, P. M. (2015). Working capital management and SMEs profitability: Portuguese evidence. International Journal of Managerial Finance, 11(3), 341-358. http://doi.org/10.1108/IJMF-11-2014-0170

Park, C. (1951). Working Capital and The Operating Cycle. The Accounting Review, 26(3), 299-307.

Pastor, C. C., \& Gama, P. M. (2013). Determinant factors of cash holdings : Evidence from Portuguese SMEs. International Journal of Business and Management, 8(1), 104-113. http://doi.org/10.5539/ijbmv8n1p104

Ramiah, V., Zhao, Y., \& Moosa, I. (2014). Working capital management during the global financial crisis: the Australian experience. Qualitative Research in Financial Markets, 6(3), 332-351. http://doi.org/10.1108/QRFM-09-2012-0026

Samiloglu, F., \& Demirgunes, K. (2008). The effect of working capital management on firm profitabilitu: evidence from Turkey. The International Journal of Applied Eonomics and Finance, 2(1), 44-50. 
SME Annual Report. (2013). released by the Secretariat of the National SME Development Council on September 24, 2013. Available at http://www.google.com/url? $\mathrm{sa}=\mathrm{t} \& \mathrm{rct}=\mathrm{j} \& \mathrm{q}=\&$ esrc $=\mathrm{s} \&$ frm $1 \&$ source $=$ web\& $\mathrm{cd}=1 \& \mathrm{ved}=0$ CCUQFjAA\&url $=\mathrm{http} \% 3 \mathrm{~A}$ $\% 2 \mathrm{~F} \% 2 \mathrm{Fwww}$.smecorp.gov.my\%2Fvn2\%2Fnode\%2F717\&ei=8M1AU9yKHM_OrQeF 1IC4Cg\&usg=AFQjCNHtd242V6O098JZm2e7g0Oc9 ghHKw; retrieved on May,18 2016

Singh, H. P., \& Kumar, S. (2014). Working capital management: a literature review and research agenda. Qualitative Research in Financial Markets, 6(2), 173-197. http://doi.org/10.1108/QRFM-04-2013-0010

Tauringana, V., \& Afrifa, G. A. (2013). The relative importance of working capital management and its components to SMEs' profitability. Journal of Small Business and Enterprise Development, 20(3), 453-469. http://doi.org/10.1108/jsbed-12-2011-0029

Wasiuzzaman, S. (2015). Working capital and firm value in an emerging market. International Journal of Managerial Finance, 11(1), 60-79. http://doi.org/10.1108/IJMF-01-20130016

Weinraub, J. H., \& Visscher, S. (1998). Industry practice relating to aggressive conservative working capital policies. Journal of Financial and Strategic Decisions, 11(2), 11-18.

Yadav, R.A. (1986). Working capital management - A parametric approach, The Chartered Accountant, 535-552.

Zariyawati, M. A., Annuar, M. N., Taufiq, H., \& Rahim, A. S. A. (2009). Working capital management and corporate performance: Case of Malaysia. Journal of Modern Accounting and Auditing, 5(11), 47-54. 